\title{
Legislation on Dental Practice in Croatia in the Second Half of the 19th Century
}

\author{
Nikola Volarićc ${ }^{1,2}$, Jelena Jakab, ${ }^{1,2}$ Miro Gardaš ${ }^{3}$ and Aleksandar V̌̌ev ${ }^{1}$ \\ ${ }^{1}$ Department of Pathophysiology, Physiology and Immunology, Faculty of Dental Medicine and Health Osijek, Josip Juraj Stross- \\ mayer University of Osijek, Osijek, Croatia \\ ${ }^{2}$ Faculty of Medicine Osijek, Josip Juraj Strossmayer University of Osijek, Osijek, Croatia \\ ${ }^{3}$ Department for Legal History and Roman Law, Faculty of Law Osijek, Josip Juraj Strossmayer University of Osijek, Osijek, Croa- \\ tia
}

\begin{abstract}
A B S T R A C T
In the second half of the 19th century, Croatia experienced a radical change in the performance of dental practice and legislation that regulates such practice. From the old feudal system when dental practice was practised by barbers-surgeons and feldshers (Old Croatian language: vidari), it is transferred to a more modern system where dental practice becomes a part of medical sciences and its implementation requires adequate medical education. The most important factor that contributed to this was the adoption of new modern laws in 1874, and then in 1894, as well as accompanying regulations, which adequately regulated the matter of public health and dental practice.
\end{abstract}

Key words: dental care history, dentistry, dental legislation, health care reform

\section{Introduction}

After the abolition of the serfdom and the transition of Croatia from feudal to civil society, in the mid-19 ${ }^{\text {th }}$ century, there was a need for a series of reforms, which would modernize the archaic, feudal way of functioning of the state. In almost all elements of the state system, from administration, judiciary, education, public health, etc., there was a need to introduce fundamental changes that would modernize the old municipal, feudal system and adapt it to changed social circumstances. A number of crucial laws that transformed the administration and judiciary from the feudal to the civil system were soon adopted, followed by reforms of other elements of state power.

There have been withdrawals and retreats along the way, but there is a general tendency towards modernization and adjustment of the social system to the new social order.

The key period came after the Croatian-Hungarian Settlement in 1868, when a number of state authorities and affairs transferred into the autonomous jurisdiction of the Kingdom of Croatia, Slavonia and Dalmatia, and enabled the separation of jurisdictions in these affairs from Hungary. It is a particularly favourable circumstance that soon after the Settlement, Ivan Mažuranić became the Croatian Ban. For many years he participated in the state apparatus of the Austrian Empire, i.e. the Austro-Hungarian Monarchy, and was familiar with all bureaucratic ways. In addition, Mažuranić was aware that in Croatia it was necessary to carry out substantial reforms in almost all areas that fell under autonomous affairs, and he approached this decisively.

\section{Dental Practice in Croatia before the Implementation of Reforms}

Until the Mažuranić' era, the dental practice in Croatia, as well as the general state of public health, was still based on outdated foundations dating from the $18^{\text {th }}$ century.

In 1737, a military hospital was established in Osijek, which operated until the collapse of the Austro-Hungarian Monarchy. Over time, several wards were established within the military hospital: internal medicine ward, infectious disease ward, skin and venereal disease ward, and of course the surgical ward, where numerous military garrisons in the city were treated.

In 1739 , the first civic hospital was established in Osijek that was supported by the alms and gifts from rich citizens. It was situated in a special building in the area 
of today's City garden and operated until 1874 when the new Huttler - Kohlhofer - Monsperger hospital in the Lower Town was built.

In 1809 , the city of Osijek gained the status of a free royal city and powers were delegated to it, which were exercised by other state authorities until that moment. One of them was being in charge for the implementation of health measures in the city. For the exercise of powers delegated to it, the city employed several officials, among them a city doctor with an annual salary of 200 forints, a feldsher (Old Croatian: ranarnik) with a salary of 100 forints, and a midwife with a salary of 100 forints $^{1}$.

This practice continued after the abolition of the feudal system, as evidenced by the fact that in 1850, after the abolition of serfdom, Emperor Francis Joseph issued a special Imperial Patent of 7 September 1850, establishing the Municipal Order for the Royal City of Ossek, in which paragraph 79 stipulates that "the Municipal Council regulates and manages the local health care according to the existing laws." (Translator's note: the original quote is written in Old Croatian language $)^{2}$.

This did not change anything in the jurisdiction and in everyday practice, but continued the practice of implementing and the functioning of public health in the manner determined by the deed of donation from 1809 when granting the status of a free royal city. In the everyday life of the citizens of Osijek, but also the rest of Croatia, that meant that dental practice was performed by barbers and feldshers who had the authority to deal with the so-called minor surgery ${ }^{3}$.

Dental and medical practice was performed by feldshers and barbers, who also performed minor surgical procedures. They mostly came to Slavonia with the army, and they continued to practice surgery after being dismissed from service. They also mainly attended military schools, and for some of them evidence was found that they were educated at the University in Buda ${ }^{4}$.

Data on barbers-surgeons who performed dental practice during the $18^{\text {th }}$ and the first half of the $19^{\text {th }}$ century can be found in the diaries of two Osijek monasteries, the Jesuit and the Franciscan, as well as in the diary of the fortress pastor Turkovićs.

\section{Dental Practice According to the Law of 1874}

With such an outdated system of dental and general medical care, Croatia welcomed the seventies of the $19^{\text {th }}$ century and the great reforms that Ban Ivan Mažuranić began to implement. In his reform process, Mažuranić touched on almost every part of the state government, and of course public health, which included dental care.

He started the reform of this area of everyday life and of the powers of the state by passing the fundamental Law on the organization of health services in Croatia and Slavonia in 1874 . This Law prescribed in detail the competencies and activities in the field of public health ${ }^{6}$.
The Royal Croatian-Slavonian-Dalmatian Provincial Government has been designated as the supreme body for the care of public health in Croatia and Slavonia.

Sub-counties, cities and municipalities with an appointed magistrate were at lower levels responsible for enforcing the Law and Government decisions. Sub-county doctors and veterinarians (Old Croatian: živinari) have been appointed for the professional performance of work in sub-counties, and in cities, special bodies in charge of health-care have been appointed by city representatives.

Political municipalities, in the so-called transferred scope of work, also implemented all other health regulations and dealt with health administrative affairs entrusted to them by the Government.

Sub-county doctors in the area of each sub-county performed a number of duties in the implementation of measures for the protection of public health. They supervised health care and medical staff employed in the state, municipal or private service in the sub-county, supervised the implementation of health regulations, as well as regulations on quackery, and trade in poisons and drugs, etc.

Pursuant to the provisions of this Act, the National Health Council was appointed, which was the government's advisory body in all matters related to health. This Council was composed of regular members: a government rapporteur on health affairs, a provincial veterinarian (Old Croatian: zemaljski veterinar) and at least four doctors, as well as associate members who were appointed as needed on a case-by-case basis.

In addition to this fundamental law, a number of instructions and provisions had been adopted which regulated in detail certain areas of public health, and in this way a truly effective network of regulations that regulated this area had been created. Among the most important are: An instruction for sub-county doctors and for city physicians 7 , the Order for Medical Assemblies (Old Croatian: Red za zborove liekarske), and a number of others that regulated many aspects of public health in detail 7 .

One of these regulations, the Instruction for sub-county doctors and city physicians, also included the "Price list on minimum rewards for private practice of both sub-county doctors and city physicians, and available feldshers, as well as private doctors", where fees for only thirty procedures were prescribed, among them few in the oral cavity. However, fees for the performance of dental procedures felt under the provision in point 29 of the Price list stipulating that fees for medical procedures not prescribed by this price list will be "assessed according to other similar activities" 8 .

\section{Dental Practice According to the Law of 1894}

As substantial territorial and administrative changes took place in Croatia in the 1890 s, and the Military Frontier (Vojna Krajina) being integrated in the meantime, in 1894 a new law was passed on the organization of the 
health service in the Kingdoms of Croatia-Slavonia. After twenty years of application of the Law of 1874, there was a need for a new law. Not so much because of the shortcomings of the old law or because of the introduction of some major innovations, but because of the harmonization with the territorial and administrative changes that have taken place in the meantime.

According to the provisions of this Law, the Land Government is also responsible for the management and supervision of all public health activities in the Kingdom of Croatia-Slavonia, and within the Government there was a special health department and a Provincial Health Council.

Public health activities in the areas of counties and cities, as well as the area of the Market-town of Ruma, were performed by county physicians and county health committees, i.e. city doctors, city health committees and city midwives, and in district areas by district doctors ${ }^{9}$.

The basic intention of the legislator was that the introduction of county and city health committees actually takes into account the facts about the specific situation on the field, i.e. in each county and city, and thus results in better and more efficient implementation of state government measures on public health care.

It is also prescribed that in cities with up to 5,000 inhabitants, one doctor should be appointed, in those up to 10,000 inhabitants, two doctors, in those up to 20,000 inhabitants, three doctors, and in those with over 20,000, one doctor for each further 10, 000 inhabitants ${ }^{9}$.

The Act of 1894 also stipulates that only a person who is a doctor of medicine, surgery, master of midwifery or a doctor of general medicine who has graduated or whose foreign degree has been nostrificated at the Royal University of Francis Joseph I in Zagreb or at another Hungarian or Austrian university, and who speaks Croatian or Serbian may be employed in public or municipal service.

Attempts were also made to bring order to the practice of private medical and general health practice. The medical staff included doctors, feldshers, midwives and pharmacy staff. It is prescribed that every private doctor $(\mathrm{Old}$ Croatian: sukromni liječnik) who settles in the Kingdom of Croatia-Slavonia should submit his diploma to the competent county district, i.e. city government, and then the county or city physician will examine it, and then issue a decision on whether he can practice medicine. The county or city physician supervised all private doctors and feldshers (paramedics) in the county or city, kept records of all medical staff, including those who performed private practice. The county or city physician was also supposed to prevent unauthorized medical practice ${ }^{10}$.

Until then, in fact, in everyday medical practice, and especially dental, the state of affairs were quite complex. There was a significant number of persons who had acquired a school degree in medicine, surgery and dental care, according to the old regulations from the feudal period, and of course they could not be prohibited from practising medicine.
The so-called non-graduated physicians, and feldshers included patrons, masters, and doctors of surgery. The lowest level of medical profession was the patron of surgery, who was required to have completed "normal" school and to have studied with a civil feldsher for three years, after which he received a scientific paper. It is especially pointed out that the patrons of surgery could take the exam for engaging in dentistry. It should be noted that this degree of medical apprenticeship has never been considered an academic education.

The next level of the so-called. non-graduated medical staff were masters of surgery. They had to complete six grades of high school and then complete lower medical-surgical studies at the university.

Doctors of surgery are those who have previously obtained a medical doctorate and subsequently took the exams to obtain a doctorate in surgery ${ }^{10}$.

However, in Hungary, schools for surgeons were abolished in 1872 , and in some provinces of the Monarchy, diplomas for feldshers could be obtained by 1885, and the provisions governing the acquisition of a doctorate in surgery were enacted "before $1850 " 10$. The new provisions sought to unify the practice and unify the training of medical staff, i.e. medical professions. Persons who, under the old regulations, had acquired titles and powers to practice medicine, could not be prohibited from performing such practices, but an attempt was made to fit them into a modernized system. Smrekar's remark is also symptomatic: "it will be that the patrons and doctors of surgery are already completely extinct or at least close to extinction."

The Order of the Royal Croatian-Slavonian-Dalmatian Government of 13 February 1892, No. 33,317, which prescribes the scope of work of dental technicians, also testifies to the continuous care of the state in introducing order in the performance of dental practice. This act explicitly stipulates that "dental technicians" cannot be considered dentists and are not allowed to perform any surgical procedures in the mouth or perform dental practice. If dental technicians did perform such procedures, they could be punished as quacks. Dental technicians who wanted to make artificial teeth or dentures had to submit applications in accordance with the law of trades and they were entered in the list of craftsmen and issued a trade card ${ }^{11}$.

On June 15, 1894, the Royal Croatian-Slavonian-Dalmatian Provincial Government issued a special Order, which was in fact an implementing act for the competencies of city and municipal doctors, and in accordance with the provisions of the 1894 Act. This Order contained, in the form of an appendix, a special Price List of awards for individual medical duties in private medical practice. It contained an appendix A, in which the prices for general medical procedures were prescribed; patient visits, hours and mileage, microscopic and other examinations, and a number of other procedures, as well as an Annex B, which prescribed prices for surgical, midwifery, eye and dental procedures, and which consisted of four parts. In the first part, prices were prescribed for about 200 surgical proce- 
dures, including a dozen in the oral cavity. In the second and third part, the prices for midwifery and eye surgeries were prescribed, and in the fourth part, the "Dentist's Price List" were prescribed.

This Price List prescribed prices for about 30 dental procedures, from tooth extraction to "finishing the entire upper or lower row of teeth on rubber", and prices ranged from 1 to 100 forint ${ }^{11}$.

\section{Conclusion}

In the period that is the subject of this paper, dental care in Osijek and the rest of Croatia has undergone a process of substantial reform and modernization. In the first part of this period from the 1850 s to the 1870 s, dental care was based on outdated foundations inherited from the feudal period. Dental practice and dental care were included in the so-called minor surgery and in everyday practice they were performed by feldshers and minor surgeons. After the Croatian-Hungarian Settlement in 1868, the care of public health was transferred into autonomous affairs under the jurisdiction of the Croatian government, which paved the way for sweeping reforms carried out during the reign of Ban Ivan Mažuranić. The Act on Health Care Regulation in Croatia and Slavonia of 1874 and a number of accompanying regulations were passed, followed by the Act of 1894 with accompanying regulations. These laws and regulations introduced in Croatia and Slavonia a fairly advanced system of legislation and care for public health, and thus for dental care and dental practice, which remained in force until the collapse of the Austro-Hungarian Monarchy. It is especially significant that the Act of 1894 actually incorporates training for dentists into the general system of medical training and thus the dental practice is finally separated from the so-called minor surgery and is being treated as an equivalent to other medical professions.

A special contribution of the Laws of 1874 and 1894 was that they introduced a fairly modern public health system in Croatia, compatible with the administrative system. Such a system enabled the efficient care of all segments of public health in Croatia and Slavonia in an efficient way, which was supported by a strong and well-established administrative system and administrative bodies.

It should be noted that special attention was paid to the protection and prevention of infectious diseases (plagues). Both human diseases, especially plague, cholera and smallpox, and livestock diseases, especially bovine plague, so the occurrence of the same was rare. In archival funds from the second half of the 19th century there is a number of orders and instructions on how to act in cases of outbreaks. However, the great concern of the legislator is also visible in prescribing a price lists for a large number of medical procedures, and thus the procedures of everyday dental practice. In this way, possible abuses are avoided, but also a thorough insight into the daily dental practice and procedures that dentists have carried out in their daily work is provided.

\section{Acknowledgement}

This paper is a product of work that has been fully supported by the Faculty of Law Osijek Josip Juraj Strossmayer University of Osijek under the project No. IP-PRAVOS-17, „Razvoj hrvatske privatnopravne tradicije u kontekstu njene integriranosti u europsku pravnu kulturu" (Development of Croatian private legal tradition in the context of its integration into European legal culture).

\section{R E F E R E N C E S}

1. SR ̌̌AN S, The Free and Royal City of Osijek 1809 (State Archive in Osijek, Osijek, 2009). - 2. DIWALD, C, Carski patent od 7. rujna 1850. kojim se odobrava iu kriepost stavlja privremeni Obćinski Red za kraljevski grad Ossek. (C. Diwald, Osijek, 1850). - 3. SKENDEROVIĆ R, Scrinia slavonica, 5/1 (2005) 115. - 4. MANDIĆ Z, ĐEŠKA S, UTVIĆ $\mathrm{V}$, The beginnings of odonto-dentistry in Osijek. In: Proceedings of 4th Symposium of Dentists of Slavonia and Baranja (Osijek, 1975). - 5. SRŠAN S, Osijek Chronicles 1686 - 1945 (Historical Archive in Osijek, 1993). - 6. Sbornik zakonah i naredabah valjanih za kraljevinu Hrvatsku i Slavoniju, god.1874, XXIII/ 53 (1875) 435. - 7. VEŽIĆ M,
Pomoćnik za javnu upravu, 1 (1884) 93. - 8. Sbornik zakonah i naredbah valjanih za Kraljevinu Hrvatsku i Slavoniju, br. 22633, god.1876 (Tiskara Narodnih Novinah, Zagreb, 1877). — 9. Zakon od 24. siečnja 1894. o uredjenju zdravstvene službe u kraljevinah Hrvatskoj i Slavoniji i provedbeni naputci $\mathrm{k}$ istomu od 15. lipnja 1895. br. $20.315 \mathrm{i}$ br. 24.209 (Zagreb 1894). - 10. SMREKAR M, Priručnik za političku upravnu službu u kraljevinah Hrvatskoj i Slavoniji, knj. I. (Tiskom i nakladom Ignjata Granitza, Zagreb, 1899). — 11. Priručnik za političku upravnu službu u kraljevinah Hrvatskoj i Slavoniji, knj. III (Tiskom i nakladom Ignjata Granitza, Zagreb, 1902).

\section{N. Volarić}

Department of Pathophysiology, Physiology and Immunology, Faculty of Dental Medicine and Health Osijek, Josip Juraj Strossmayer University of Osijek, Crkvena 21, 31000 Osijek, Croatia

e-mail: nikola.volaric@fdmz.hr 


\section{ZAKONSKA REGULATIVA DENTALNE PRAKSE U HRVATSKOJ U DRUGOJ POLOVINI 19. STOLJEĆA}

\section{S A Ž E T A K}

U drugoj polovini 19. st. u Hrvatskoj je došlo do korjenite promjene u obavljanju dentalne prakse i zakonskoj regulativi koja takvu praksu normira. Od staroga feudalnog sustava kada su se dentalnom praksom bavili brijači-kirurzi i vidari prelazi se u moderniji sustav $\mathrm{u}$ kojemu dentalna praksa postaje dio medicinskih znanosti i za njezino obavljanje potrebno je odgovarajuće medicinsko obrazovanje. Najvažnija okolnost koja je tome doprinijela je donošenje novih modernih zakona 1874., a potom 1894. godine, i pratećih propisa, koji su na primjeren način regulirali materiju javnoga zdravstva i dentalne prakse. 
